REPRODUCTION

\title{
There is a difference between selecting a deaf embryo and deafening a hearing child
}

\section{Häyry}

J Med Ethics 2004;30:510-512. doi: 10.1136/jme.2002.001891

If genetic diagnosis and preimplantation selection could be employed to produce deaf children, would it be acceptable for deaf parents to do so? Some say no, because there is no moral difference between selecting a deaf embryo and deafening a hearing child, and because it would be wrong to deafen infants. It is argued in this paper, however, that this view is untenable. There are differences between the two activities, and it is perfectly possible to condone genetic selection for deafness while condemning attempts to deafen infants at birth.

S ome deaf parents have argued that they are entitled to have deaf children. ${ }^{1}$ According to them, deafness is not a disability but a culture which they should be permitted to pass on to their offspring. ${ }^{2}$ One way of doing this would be to use in vitro fertilisation and preimplantation genetic diagnosis, and to select a "deaf embryo" for an attempt to start a pregnancy. ${ }^{3}$

One popular argument against this is to say that selecting a deaf embryo would not in any important sense be different from deafening a hearing child, which, in its turn, would be clearly immoral. ${ }^{4}$ My aim in this paper is to show that this argument is not sound. I believe that the analogy is misleading, and clouds the issues surrounding disability and prenatal selection.

\section{IMPERSONAL OUTCOMES}

The analogy is based on the assumption that only the objective, or impersonal, outcomes of our actions are morally relevant. The most important of these in our two cases are the following:

Correspondence to: M Häyry, Centre for Professional Ethics, University of Central Lancashire, Preston PR1 $2 \mathrm{HE}, \mathrm{UK}$.

mhayry@uclan.ac.uk

Received

21 September 2002

Revised version received

14 January 2003

Accepted 30 May 2003

As these outcomes do not differ from one choice to the other, the argument then goes on to say that if we accept one, we must also accept the other. Therefore, because the idea of deafening a hearing child would be outrageous, we cannot

\section{PERSONAL OUTCOMES}

The analogy breaks down when a more personal, or individualistic, angle is added to the considerations. The choice between embryos and the choice between deafening or not deafening a hearing child can be clearly distinguished by asking, counterfactually, who would have existed and what would have happened had the original choice not been made. The main differences are the following:

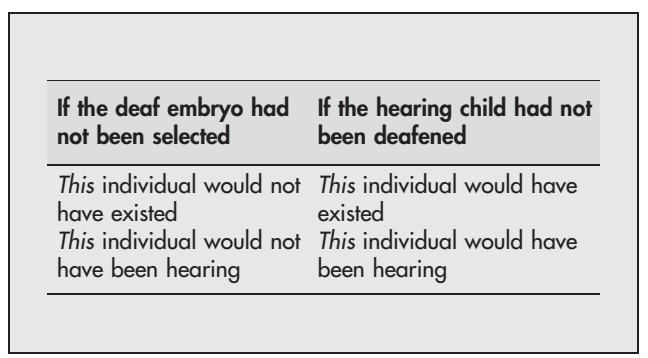

Put simply, parents who select a deaf embryo (or any embryo for that matter), give that specific potential person a chance to live, with the qualities that that individual happens to have. By contrast, parents who deafen a hearing child (or perform any other irreversible operation on their progeny) change the qualities of an already existing individual.

Seen from the viewpoint of the individuals produced, the situations look rather different. When the person chosen as an embryo matures enough to evaluate her situation, she can only conclude that the options for her were life as deaf or no life at all. ${ }^{6}$ When, in turn, the person deafened as an infant assesses his life, he sees the options once open to him as life as deaf and life as hearing.

Those who condone selecting a deaf embryo assert that it is morally acceptable to bring an individual into existence even if, or because, this individual will probably be deaf. It does not follow from this that it would be fine to change the qualities of already existing people, when it is at least arguable that the change would be for the worse. Selecting a deaf embryo is, in an important moral sense, different from deafening a hearing child, and we can, logically speaking, accept one without condoning the other. permit either. ${ }^{5}$

\section{THE REAL CHOICES}

In most Western societies, the child's best interest is seen as paramount when it comes to decisions which may concern them. ${ }^{7}$ Contrary to what people may believe, ${ }^{8}$ however, this is not normally a factor in preimplantation genetic 
selection. ${ }^{9}$ This becomes visible in an analysis of who can be affected by the decision to select a deaf embryo and how.

There are four major parties involved in the choice, namely the selected future child, the family, society as a whole, and the possible children whom the parents did not choose to implant. The effects of selecting a deaf embryo and of deafening a child on these individuals and groups are as follows:

\begin{tabular}{|c|c|c|}
\hline & $\begin{array}{l}\text { When a deaf embryo } \\
\text { is selected }\end{array}$ & $\begin{array}{l}\text { When a hearing child is } \\
\text { deafened }\end{array}$ \\
\hline The child & $\begin{array}{l}\text { Gets to live the best } \\
\text { life possible for her }\end{array}$ & $\begin{array}{l}\text { Loses a sense? Gains a } \\
\text { culture? }\end{array}$ \\
\hline The family & $\begin{array}{l}\text { Get the kind of child } \\
\text { they want }\end{array}$ & $\begin{array}{l}\text { Get the kind of child they } \\
\text { want }\end{array}$ \\
\hline Society & $\begin{array}{l}\text { Has to provide for } \\
\text { some special needs }\end{array}$ & $\begin{array}{l}\text { Has to provide for some } \\
\text { special needs }\end{array}$ \\
\hline Other children & $\begin{array}{l}\text { Do not get the best } \\
\text { lives possible for them }\end{array}$ & Not applicable \\
\hline
\end{tabular}

In the case of preimplantation diagnosis and selection, any individual who comes to existence will, other things being equal, have the best life possible for her. This means that arguments from the child's best interest cannot be used against the choice the potential parents make-whatever it is. ${ }^{10}$ The real clash occurs between the family's interest to have the kind of child they prefer, and society's claim that the production of yet another individual with special needs will place a burden on scarce resources. The real policy choice must be made between reproductive autonomy and socioeconomic considerations. ${ }^{11}$

In the case of deafening an infant, however, the child's best interest is of paramount importance. There are two competing views concerning what is best for the individual: one saying that deafness is a disabling condition which ought to be avoided, and the other stating that it is a rich culture to which parents should be entitled to introduce their children. Policy decisions must be based on a choice, or a compromise, between these clashing interpretations.

\section{POSSIBLE SOLUTIONS}

As the analogy between selecting deaf embryos and deafening existing children is untenable, the policy solutions can be different in each case. This leaves open four possible combinations, but let me proceed by sketching a model in which the preimplantation choice is left to the parents, with no moral strings attached, while the hearing of existing children is protected even against their wishes. ${ }^{12}$

Freedom in embryo selection can be defended by an appeal to reproductive autonomy, which has recently been recognised in several international agreements. ${ }^{13}$ According to the ethos of these agreements, people should be left free to make any decisions concerning their offspring, as long as they do not harm their children, or other innocent third parties, in the process. Because life-hearing or deaf-is not normally seen as a harm, parents cannot be said to damage any (otherwise relatively healthy) children they produce. ${ }^{14}$ And because other people-hearing or deaf-are not in any real sense injured by the parents' choice (whatever it is) people should be entitled, morally as well as legally, to bring into existence the kind of children they want. ${ }^{15}$

Decisions to interfere with the bodily integrity of an already existing child, on the other hand, do not fall within the scope of reproductive autonomy. The question here is what is in the best interest of the child. The deaf parents' argument must be that the child will be better off as a member of the deaf culture. There are, however, considerations which may go against this claim. If the parents die before the child reaches maturity, and if the deaf community is not sufficiently well established, the deafened individual may face all sorts of problems in her life later on. She may then come to think, not unreasonably, that in their well meant attempt to offer her one specific culture, her parents have actually deprived her of the means to flourish in another culture, the culture in which she eventually has to live.

Similar considerations cannot readily be extended to the reverse case, where society has stepped in and prevented the parents from deafening the child. The child will be brought up to cope with both cultures - the deaf and the hearingand whatever happens to his parents, he will be able to live his life without excessive difficulties. If hearing is a burden to him he can, when he has reached maturity and if he genuinely wants it, deafen himself and join the deaf culture. The early experiences in that culture as a child will be lost, but he will still have the chance to decide for himself, which is more than can be said for the alternative scenario.

\section{POTENTIAL OBJECTIONS}

To recapitulate, I have argued that selecting a deaf embryo and deafening a hearing child can be conceptually and morally distinguished. The cases are similar, if only impersonal outcomes are taken into account, but they are different as regards who would have lived and what would have happened, had the choice not been made. In the first case, a deaf future individual is given the chance to live the best life possible for him or her. In the second case, the qualities of a hearing individual are changed to accommodate the wishes of his parents.

I have also given some reasons for thinking that although it is morally acceptable to select a deaf embryo, it is not morally acceptable to deafen a hearing infant. The freedom to select can be supported by appeals to reproductive autonomy, but the child's best interest will probably not be served by deafening him.

Those who believe that we should always produce "the best children we can" are likely to argue, against my conclusions, that deafness is a disability, and that we should never deliberately bring disabled individuals into existence. My question to them is, why not? All human beings live the best life they can, and if life is a good thing, then why deprive some potential individuals of that opportunity because of their personal qualities?

Others who think that deaf embryos should not be selected can make an appeal to the adverse socioeconomic implications of the choice. They can argue that prospective parents have no right to burden society with the extra cost of providing for the special needs of their "unnecessarily" deaf offspring. These critics of selection face two challenges. Trading freedom for economic gain is a sensitive issue, especially when it comes to reproductive freedom. And it is difficult to judge whose existence, qualities and, consequently, needs, can be deemed as unnecessary.

Those who believe that parents should be entitled to change the qualities of their existing children, in their turn, can argue that my solution favours unreasonably the only culture I am familiar with, namely, the hearing culture. My response to them is that I have not made any value judgements between the deaf and the hearing cultures. I have only argued that the freedom of choice of the child can be better preserved by choosing the option which is, to a fair degree although not completely, reversible when the individual is mature enough to make his own decisions. 


\section{REFERENCES}

1 See, for example, Spriggs M. Lesbian couple create a child who is deaf like them. J Med Ethics 2002;28:283; Levy N. Deafness, culture, and choice. $J$ Med Ethics 2002;28:284-5; Anstey KW. Are attempts to have impaired children justifiable? J Med Ethics 2002;28:286-8.

2 Lane $H$, Grodin M. Ethical issues in cochlear implant surgery: an exploration into disease, disability, and the best interests of the child. Kennedy Inst Ethics J 1997:7:231-51.

3 The expression "deaf embryo" is rather indiscriminately used in the discussion. Deafness in embryos cannot be directly diagnosed. What authors refer to by the expression is the possibility of identifying genetic traits which can contribute to the probability of deafness in the prospective individual. It follows from this that prospective parents cannot "deafen hearing embryos", although the language used in ethical debates sometimes seems to suggest this. If they could, this would, for the purposes of my argument, be equivalent to deafening a hearing infant.

4 Harris J. Is there a coherent social conception of disability? J Med Ethics 2000;26:95-100. Harris writes (p 97): "I do not believe that there is a difference between choosing a preimplantation deaf embryo and refusing a cure to a newborn. Nor do I see an important difference between refusing a cure and deliberately deafening a child."

5 By the way, I am not sure that the idea of deafening a child would necessarily be outrageous to all deaf parents who want to offer their children the opportunity to join their inherited culture. The idea of physically moulding children, say, by circumcision does not shock parents who believe in the cultural and spiritual value of the operation. I will, however, try to accommodate the more widely shared intuition that there is something wrong with deliberately deafening an infant.

6 This is why "wrongful life" charges against the parents would be groundless. If the individual does not like the only life she could have had, she is free to end it, but the parents cannot be accused of giving her less of a life than they could have done. Compare with, however, Harris J. Clones, genes, and immortality: ethics and the genetic revolution. Oxford: Oxford University Press, 1998:111.

7 Children Act 1989; NHS \& Community Care Act 1990; UNICEF Convention on the Rights of the Child 1989. Compare with Harris J. The welfare of the child. Health Care Anal 2000;8:27-34.

8 Davis DS. Genetic dilemmas and the child's right to an open future. Hastings Center Report 1997:27:7-15.

9 See also Takala contra Davis on the "open-future" argument in this context. Takala T. Genes, sense and sensibility: philosophical studies on the ethics of modern biotechnologies. Helsinki: Reprotalo, 2000:107-18. Compare with Chadwick R, Levitt M. Genetic technology: A threat to deafness. Med Health Care Philos 1998;1:209-15.

10 It can be argued that if the child would have "a life not worth living" (whatever this means), it would be wrong to bring her into existence. (Compare with Häyry M. Playing God: essays on bioethics. Helsinki: Helsinki University Press, 2001:32-43.) But this is not the case with deafness even according to the authors who use the analogy argument examined in this paper.See, e.g. Harris J. One principle and three fallacies of disability studies. J Med Ethics $2001 ; 27: 383-7$.
11 Some defenders of the analogy between selecting embryos and deafening a hearing child agree with this interim policy conclusion. Harris, for instance, writes: "It ... could not be said that I suggest that people should be prohibited or prevented from having children with disabilities. On the contrary, ... I have argued consistently that they have this entitlement. What I have said ... is that 'it is wrong to bring avoidable suffering into the world'. [lt does not follow] from the fact that something is wrong, that people should be prevented from doing it. ... It follows from the fact that something is morally wrong that they should not do it, but whether the doing of such things should be regulated, or prohibited by law, or punished are each, always further and separate questions." (See reference 3: Harris, p 96.) But if the wrongness of selecting deaf embryos can be overlooked in policy decisions, then what about the wrongness of deafening hearing children? Can the legislator plausibly say, according to Harris, that the immorality of harming an existing individual should or could in policy decisions be trumped by other people's preferences? If not, what makes the cases different? And if they are different, what about the claim that they are not? (See reference 3: Harris, p 97.)

12 This combination has the advantage of accommodating some intuitions from each side of the argument.

13 United Nations Universal Declaration of Human Rights, 1948

14 Not everybody agrees with this. Harris writes: "I believe that 'it is ethical to prevent the births of people with disabilities because it is right to prevent needless harm'." (See reference 8: Harris, p 387.) The question here is, "needless" for whom? If the parents can have children without detectable disabilities, the harm of having a disabled child is needless for them. But in the case of selecting a deaf embryo, the parents do not see deafness as a harm. On the other hand, the potential individual would certainly "need" her parents to accept the disability, because without the acceptance she will not be allowed to live. But talking about the needs of embryos is metaphorical at best. So should we see things from the viewpoint of the universe, and regard it as ethical to prevent the existence of all individuals who can be harmed during their lives? But as everybody can be harmed, this probably means that it would be ethical to stop procreation altogether, and let the human race die during the generations who are already in existence. But this is not something Harris would accept. See, e.g. Harris J. Wonderwoman and Superman: the ethics of human biotechnology. Oxford and New York: Oxford University Press, 1993:176-7. Compare with Häyry M. What the fox would have said, had he been a hedgehog - on the methodology and normative approach of John Harris's Wonderwoman and Superman, In: Launis V, Pietarinen J, Räikkä J eds. Genes and morality: new essays. Amsterdam and Atlanta: Rodopi, 1999:11-19.

15 When deaf people argue against selecting hearing embryos, they sometimes claim that the practice is prejudicial against them as a group. I suppose hearing people have similar ideas when they attack attempts to select deaf embryos. In both cases, it can be said, they are killing one of us. But as the embryos (or pre-embryos) do not yet exist as people when the choice is made, they are not actually harmed as people, which means that no literal killing in the ethically bad sense occurs. And in a society where people's reproductive autonomy is respected whatever they choose, there is at least no public discrimination against any group. (And private discrimination cannot be argued against, as the private sphere is protected by respect for autonomy.) 